ROCZNIKI NAUK PRAWNYCH

Tom XXX, numer $3-2020$

DOI: https://doi.org/10.18290/rnp20303-4

CZESŁAW PAWEŁ KŁAK

\title{
DOPUSZCZENIE DOWODU Z OPINII INNEGO BIEGŁEGO W POLSKIM POSTĘPOWANIU CYWILNYM I KARNYM. PODOBIEŃSTWA I RÓŻNICE
}

\section{WPROWADZENIE}

W nawiązaniu do artykułu opublikowanego „Rocznikach Nauk Prawnych” 25 (2015), nr 2 pt. „Kryteria oceny dowodu z opinii biegłego w orzecznictwie sądów powszechnych i Sądu Najwyższego" (s. 21-47) warto więcej uwagi poświęcić problematyce dopuszczenia dowodu z opinii innego biegłego. Jego autorki - Joanna Dzierżanowska i Joanna Studzińska - trafnie wskazały, że w postępowaniu cywilnym sąd z urzędu czy też w następstwie zarzutów stron, nie podzielając opinii biegłego - przy uwzględnieniu poziomu wiedzy biegłego, podstaw teoretycznych opinii i sposobu motywowania przyjętego w opinii, stanowczości wyrażonych ocen oraz zgodności z zasadami logiki wiedzy powszechnej - i pozbawiając ją mocy dowodowej, powinien powołać innego biegłego (s. 26), zaznaczając przy tym, że w ustawie z dnia 17 listopada 1964 r. - Kodeks postępowania cywilnego ${ }^{1}$ (dalej: k.p.c.) - nie ma zawartego, jasno sformułowanego, wymogu rzetelności opinii biegłego, jak również nie ma przewidzianych żadnych procedur kontrolnych, ukierunkowanych na sprawdzenie jej rzetelności (s. 31). Z kolei w odniesieniu do postępowania karnego we wskazanym artykule zasadnie podkreślono, w oparciu na art. 201 ustawy z dnia 6 czerwca 1997 r. - Kodeks postępowania karnego z 1997 r. $^{2}$ (dalej: k.p.k.), że możliwości określone w tym

Dr hab. CZESŁAW PAweŁ KŁAK, prof. KPSW - Katedra Kryminologii, Kryminalistyki, Bezpieczeństwa Wewnętrznego i Nauk Penitencjarnych, Instytut Prawa i Administracji, Kujawsko-Pomorska Szkoła Wyższa w Bydgoszczy, ul. Toruńska 55-57, 85-023 Bydgoszcz; e-mail: czeslaw klak@interia.pl; ORCID: https://orcid.org/0000-0002-2886-4770

${ }^{1}$ Tekst jedn. Dz. U. 2019, poz. 1460 z późn. zm.

${ }^{2}$ Tekst jedn. Dz. U. 2020, poz. 30. 
przepisie pozwalają na uzyskanie opinii uzupełniających, przeprowadzenia konfrontacji poglądów czy zasięgnięcie kolejnej opinii od nowych biegłych bądź od instytucji naukowej lub specjalistycznej (s. 40). Warto jest przeprowadzić szersze rozważania naukowe, celem porównania podstaw prawnych dopuszczenia dowodu z opinii innego biegłego w świetle kodeksu postępowania cywilnego i kodeksu postępowania karnego. Już na wstępie należy podkreślić, że wskazane kodyfikacje posługują się inną nomenklaturą. Kodeks postępowania cywilnego stanowi o ,zażądaniu dodatkowej opinii od [...] innych biegłych" (art. 286), podczas gdy kodeks postępowania karnego konsekwentnie posługuje się pojęciem „powołuje się innego biegłego” (art. 196 § 2 i 3) lub „można... powołać innych” (biegłych - podkreślenie Cz.P.K., art. 201 k.p.k.). Mimo różnic terminologicznych w istocie obie ustawy procesowe regulują tę samą instytucję prawną - dopuszczenie dowodu z opinii innego biegłego. Zażądanie opinii od innego biegłego (innych biegłych) w postępowaniu cywilnym i powołanie innego biegłego (innych biegłych) w postępowaniu karnym polega bowiem na tym, że organ procesowy dopuszcza dowód z opinii takiego - nowego - biegłego (biegłych), a więc podejmuje w tym zakresie rozstrzygnięcie. Jednocześnie obie ustawy procesowe posługują się pojęciem dopuszczenia dowodu $\mathrm{z}$ opinii biegłego (art. 194 k.p.k.) lub dopuszczenia dowodu z biegłych (art. 279 k.p.c.). Nie ulega wątpliwości, że wskazane przepisy znajdują zastosowanie nie tylko do powoływania biegłego (biegłych) „po raz pierwszy”, ale także do powołania innego biegłego w rozumieniu art. $196 \S 2$ i 3 k.p.k. i art. 201 k.p.k. oraz art. 286 k.p.c. Także w tych przypadkach organ procesowy dopuszcza dowód z opinii biegłego (biegłych), co nie budzi w orzecznictwie sądowym sprzeciwu, ani na gruncie kodeksu postępowania cywilnego ${ }^{3}$, ani kodeksu postępowania karnego ${ }^{4}$. Nie ulega przy tym wątpliwości, że dopuszczenie dowodu

\footnotetext{
${ }^{3}$ M.in. postanowienie SN z 11 kwietnia 2018 r., III UK 111/17, LEX nr 2497990; wyrok SA w Lublinie z 6 grudnia 2019 r., I ACa 774/18, LEX nr 2799116; wyrok SA w Warszawie z 16 października 2019 r., I ACa 520/18, LEX nr 2753902; wyrok SA w Szczecinie z 3 października 2019 r., I ACa 459/19, LEX nr 2771942; wyrok SA w Szczecinie z 24 września 2019 r., I ACa 403/19, LEX nr 2770874; wyrok SA w Warszawie z 19 września 2019 r., I ACa 483/18, LEX nr 2728639; wyrok SA w Krakowie z 22 listopada 2017 r., I ACa 535/17, LEX nr 2472497; wyrok SA w Warszawie z 15 listopada 2017 r., VII ACa 1394/17, LEX nr 2487716.

${ }^{4}$ M.in. wyrok SA w Białymstoku z 9 maja 2019 r., II AKa 58/19, LEX nr 2735140; wyrok SA we Wrocławiu z 18 października 2018 r., II AKa 128/18, LEX nr 2605253; wyrok SA w Lublinie z 16 października 2018 r., II AKa 229/18, LEX nr 2576169; wyrok SA w Krakowie z 2 października 2018 r., II AKa 254/18, LEX nr 2645335; wyrok SA w Katowicach z 1 marca 2018 r., II AKa 568/17, LEX nr 2480854.
} 
z opinii innego biegłego (biegłych) jest równoznaczne z powołaniem takiego biegłego (biegłych) .

Zestawienie art. $196 \S 2$ i 3 k.p.k. z art. 286 k.p.c. prowadzi do wniosku, że wskazane przepisy kodeksu postępowania karnego przewidują obligatoryjne powołanie innego biegłego, w każdym przypadku wystąpienia okoliczności, o których mowa $\mathrm{w}$ tych przepisach. Wynika to z posłużenia się przez ustawodawcę sformułowaniem ,powołuje się innego biegłego”. Organ procesowy nie ma możliwości podjęcia innego rozstrzygnięcia niż powołanie innego biegłego. Z kolei w art. 286 k.p.c., tak jak i w art. 201 k.p.k. ustawodawca posłużył się innym pojęciem, a mianowicie „sąd może...” (art. 286 k.p.c.) lub „można powołać innych” (biegłych - podkreślenie Cz.P.K., art. 201 k.p.k.). W orzecznictwie i piśmiennictwie na gruncie kodeksu postępowania cywilnego wyrażono pogląd, że dokonanie czynności określonych w art. 286 pozostawione jest uznaniu sądu ${ }^{6}$. W orzecznictwie Sądu Najwyższego sformułowano jednakże pogląd, że na podstawie art. 286 k.p.c. sąd ma obowiązek dopuszczenia dowodu z dodatkowej opinii biegłych, którzy wydawali już opinie w sprawie, lub z opinii dalszych biegłych, gdy zachodzi taka potrzeba, a w szczególności, gdy przeprowadzona już opinia (bądź opinie) zawiera (zawierają) istotne luki, jest nieprzekonująca, niekompletna, pomija lub wadliwie przedstawia istotne okoliczności, nie odpowiada na postawione tezy dowodowe, jest niejasna, nienależycie uzasadniona czy nieweryfikowalna. Sąd narusza więc art. 286 k.p.c., odrzucając w takiej właśnie sytuacji opinię biegłego i polemizując $\mathrm{z}$ jego wnioskami w sferze wymagającej wiadomości specjalnych, bez zasięgnięcia opinii innego biegłego ${ }^{7}$. Z kolei w orzecznictwie sądów apelacyjnych podkreślono, że sąd ma obowiązek dopuszczenia dowodu $z$ dalszej opinii, gdy zachodzi taka potrzeba, a więc wtedy, gdy opinia, którą dysponuje, zawiera istotne luki, bo nie odpowiada na postawione tezy dowodowe, jest niejasna, czyli nienależycie uzasadniona lub nieweryfikowalna, tj. gdy przedstawiona przez eksperta analiza nie pozwala organowi orzekającemu skontrolować jego rozumowania, co do trafności jego wniosków końcowych ${ }^{8}$. Wadliwość opinii obliguje zatem sąd do zastoso-

\footnotetext{
${ }^{5}$ M.in. wyrok SA w Gdańsku z 26 stycznia 2018 r., V AGa 19/18, LEX nr 2522657.

${ }^{6}$ T. EReciński, [w:] T. EREcińsKi, J. Gudowski, M. JęDRZEJewsKA, Komentarz do kodeksu postępowania cywilnego. Część pierwsza. Postępowanie rozpoznawcze, t. I, red. T. Ereciński, Warszawa: LexisNexis 2003, s. 567; wyrok SN z 17 grudnia 1999 r., II UKN 273/99, LEX nr 46509.

${ }^{7}$ Wyrok SN z 4 sierpnia 2016 r., III UK 195/15, LEX nr 2155187; wyrok SN z 13 stycznia 2016 r., V CSK 262/15, LEX nr 2020486.

${ }^{8}$ Wyrok SA w Gdańsku z 10 maja 2016 r., V ACa 776/15, LEX nr 2108564.
} 
wania art. 286 k.p.c. ${ }^{9}$ Mimo zatem posłużenia się przez ustawodawcę sformułowaniem „sąd może” przyjmuje się, że jego obowiązkiem jest zastosowanie art. 286 k.p.c. w przypadku, gdy niezbędne jest zweryfikowanie złożonej przez biegłego opinii ${ }^{10}$. Podzielam ten kierunek wykładni. Celem art. 286 k.p.c. jest stworzenie podstaw do weryfikacji opinii biegłego w sytuacji, gdy w wyniku oceny, o której mowa w art. 233 § 1 k.p.c., sąd uzna, że nie spełnia ona wymogów odnoszących się do tego dowodu i nie pozwala na poczynienie ustaleń faktycznych w sprawie. Uznaniu sądu pozostawiono natomiast wybór sposobu owej weryfikacji, co wyraźnie wynika z brzmienia art. 286 k.p.c. Również na gruncie art. 201 k.p.k. należy przyjąć, że przepis ten przewiduje obowiązek jego zastosowania, gdy spełnione będą określone w nim przesłanki. Jak wskazano w orzecznictwie sądowym, dowód z opinii innych biegłych dopuszcza się (a więc nie tylko można dopuścić - podkreślenie Cz.P.K.) wtedy, gdy dotychczasowa opinia pochodzi od biegłych podlegających wyłączeniu albo niekompetentnych (art. 196 § 2 i 3 k.p.k.), bądź gdy jest ona niepełna albo niejasna, wewnętrznie sprzeczna lub zachodzi sprzeczność między różnymi opiniami w tej samej sprawie (art. 201 k.p.k.) ${ }^{11}$. Wskazany przepis określa dyrektywę postępowania (a więc wskazuje, jak organ procesowy powinien postąpić), nakazując alternatywne postępowanie, polegające na wezwaniu ponownym tych samych biegłych lub powołaniu innych ${ }^{12}$. Wynika $z$ niego zatem dwojaki sposób rozwiązania problemu opinii niejasnych, niepełnych, sprzecznych wewnętrznie lub między sobą. To organ procesowy przeprowadzający postępowanie dowodowe podejmuje decyzję, czy wezwać ponownie tych samych biegłych, czy też powołać innych w zależności od tego, które $\mathrm{z}$ tych rozwiązań - w realiach konkretnej sytuacji procesowej - uzna za realizujące w większym stopniu cel wytyczony przez dyrektywę wynikającą z dyspozycji powołanego wyżej przepisu ${ }^{13}$. Swoboda organu procesowego dotyczy zatem wyboru sposobu weryfikacji opinii biegłego, nie polega zatem na uznaniowości w zakresie samej decyzji o zastosowaniu art. 201 k.p.k. - gdy wystąpią okoliczności, o których mowa w tym przepisie. Finalnie należy - w świetle powyższych uwag - podzielić pogląd, że wprawdzie art. 201 używa sformułowania „sąd może”, ale w przypadku,

\footnotetext{
${ }^{9}$ Wyrok SN z 8 października 2015 r., I UK 447/14, LEX nr 1820395; wyrok SA w Gdańsku z 4 listopada 2015 r., III AUa 819/15, LEX nr 1950626.

${ }^{10}$ Wyrok SA w Krakowie z 9 września 2015 r., I ACa 705/15, LEX nr 1820414.

${ }^{11}$ Wyrok SA w Krakowie z 2 października 2018 r., II AKa 254/18, LEX nr 2645335.

${ }^{12}$ Wyrok SA we Wrocławiu z 9 kwietnia 2014 r., II AKa 70/14, LEX nr 1459125.

${ }^{13}$ Postanowienie SN z 27 lipca 2016 r., V KK 25/16, LEX nr 2108096.
} 
w którym ujawnią się okoliczności, o których mowa w tym przepisie, dążenie do wyjaśnienia niejasności i sprzeczności jest obowiązkiem organu procesowego, zaś zaniechanie tych czynności może doprowadzić do podniesienia zarzutu niewyjaśnienia wszystkich istotnych okoliczności sprawy ${ }^{14}$. Jak trafnie zaznaczono w piśmiennictwie i orzecznictwie, wprawdzie art. 201 k.p.k. mówi jedynie o „możliwości”, a nie o „obowiązku”, jednak swoboda sądu w ocenie okoliczności wymagających wiadomości specjalnych nie może być nieograniczona, co powoduje, że w pewnych sytuacjach, przewidziana w art. 201 „możliwość” powołania innych biegłych przeobraża się w „obowiązek”15. Jeżeli opinia zawiera uchybienia enumeratywnie wymienione w art. 201 k.p.k., sąd (organ procesowy - podkreślenie Cz.P.K.) nie może pozostać bierny i nie zastosować jednego z wariantów ich usunięcia, albowiem dążenie do wyjaśnienia niejasności i sprzeczności jest obowiązkiem sądu (organu procesowe - podkreślenie Cz.P.K.) ${ }^{16}$. Obowiązkiem orga$\mathrm{nu}$ procesowego jest we wskazanym przypadku albo ponowne wezwanie dotychczasowego biegłego, albo też powołanie innego ${ }^{17}$. Pogląd taki ${ }^{18}$ prezentowany był również na gruncie art. 182 ustawy z dnia 19 kwietnia $1969 \mathrm{r}$. - Kodeks postępowania karnego ${ }^{19}$ (dalej: k.p.k. z 1969 r.). Art. 201 k.p.k. zastąpił, z pewnymi zmianami, art. 182 k.p.k. z 1969 r.

\section{PODSTAWY DOPUSZCZENIA DOWODU Z OPINII INNEGO BIEGLEGO}

Kodeks postępowania cywilnego w art. 286 stanowi, że „Sąd może zażądać ustnego lub pisemnego uzupełnienia opinii lub jej wyjaśnienia, a także

\footnotetext{
${ }^{14}$ P. HofmaŃSKI, E. SADZIK, K. ZgrYZeK, Kodeks postępowania karnego. Tom I. Komentarz do artykułów 1-296, red. P. Hofmański, Warszawa: C.H. Beck 2011, s. 1144 i cytowane tam piśmiennictwo oraz orzecznictwo.

${ }^{15}$ R.A. STEFAŃSKI, [w:] Kodeks postepowania karnego. Komentarz, t. II, red. R.A. Stefański i S. Zabłocki, Warszawa: Wolters Kluwer 2016, teza 2 do art. 201; wyrok SA w Lublinie z 18 października 2012 r., II AKa 243/12, LEX nr 1237271.

${ }^{16}$ Wyrok SN z 6 listopada 2002 r., IV KKN 308/99, LEX nr 56851; zob. także: postanowienie SN z 21 września 1975 r., Z 24/75, OSNKW 1975, nr 12, poz. 172; wyrok SN z 9 maja 1988 r., OSNKW 1988, nr 9-10, poz. 72; wyrok SN z 12 maja 1988 r., II KR 92/88, OSNKW 1989, nr 2, poz. 35; wyrok SN z 20 kwietnia 1984 r., RNw 27/83, OSNPG 1984, nr 11, poz. 102; postanowienie SN z 26 czerwca 2008 r., V KK 206/08, OSNwSK 2008/1/1350; wyrok SA w Rzeszowie z 21 lutego 2013 r., II AKa 7/13, LEX nr 1280995.

${ }^{17}$ Wyrok SN z 7 października 2009 r., III KK 122/09, LEX nr 532391.

${ }^{18}$ S. KalinowsKI, [w:] Kodeks posteppowania karnego. Komentarz, red. M. Mazur, Warszawa: Wydawnictwo Prawnicze 1976, s. 263.

${ }^{19}$ Dz. U. 1969, nr 13, poz. 96 z późn. zm.
} 
dodatkowej opinii od tych samych lub innych biegłych". Identyczne rozwiązanie przewidziano $\mathrm{w}$ odniesieniu do opinii instytutu naukowego lub naukowo-badawczego. Zgodnie z art. 290 § 3 k.p.c. „Sąd może zażądać ustnego lub pisemnego uzupełnienia opinii lub jej wyjaśnienia, a także dodatkowej opinii od tego samego lub innego instytutu naukowego lub naukowo-badawczego". Obecne brzmienie art. 286 k.p.c. i art. 290 § 3 k.p.c. wynika z ustawy z dnia 4 lipca 2019 r. o zmianie ustawy - Kodeks postępowania cywilnego oraz niektórych innych ustaw ${ }^{20}$ (art. 1 pkt 101 oraz art. 1 pkt 103), przy czym art. 286 k.p.c. został zmieniony przez wskazaną ustawą, zaś art. $290 \S 3$ dodany do kodeksu. Są to jedyne przepisy proceduralne, z których wyraźnie wynika możliwość dopuszczenia w postępowaniu cywilnym dowodu $\mathrm{z}$ opinii innego biegłego, przy czym art. $290 \S 3$ k.p.c. znajduje odpowiednie zastosowanie do opinii opiniodawczego zespołu sądowych specjalistów (art. $290^{1}$ k.p.c.).

Inne rozwiązanie, niż wskazane powyżej, przyjęto w kodeksie postępowania karnego, w którym szerzej zakreślono możliwość powołania innego biegłego. Jak wynika z art. $196 \S 2$ k.p.k., „Jeżeli ujawnią się przyczyny wyłączenia biegłego wymienione $\mathrm{w} \S 1$, wydana przez niego opinia nie stanowi dowodu, a na miejsce biegłego wyłączonego powołuje się innego biegłego". Zgodnie z brzmieniem art. $196 \S 1$ k.p.k. nie mogą być biegłymi osoby wymienione w art. 178 k.p.k., art. 182 k.p.k. i 185 k.p.k. oraz osoby, co do których odnoszą się odpowiednie przyczyny wyłączenia wymienione w art. $40 \S 1$ pkt 1-3 i 5, osoby powołane w sprawie w charakterze świadków, a także osoby, które były świadkiem czynu. Ponadto, „Jeżeli ujawnią się powody osłabiające zaufanie do wiedzy lub bezstronności biegłego albo inne ważne powody, powołuje się innego biegłego" (art. 196 § 3 k.p.k.).

Przywołany już art. 201 k.p.k. przewiduje podstawę prawną do powołania innego biegłego (innych biegłych) ze względu na ocenę opinii dotychczasowego biegłego. Przepis ten znajduje zastosowanie w przypadku, gdy opinia biegłego jest niepełna, niejasna albo gdy zachodzi sprzeczność w samej opinii lub między różnymi opiniami w tej samej sprawie.

$\mathrm{Z}$ powyższego wynika, że w postępowaniu karnym przewidziano powołanie innego biegłego w trzech przypadkach: gdy ujawnią się podstawy do wyłączenia biegłego (art. $196 \S 1$ i 2 k.p.k.); gdy ujawnią się powody osłabiające zaufanie do wiedzy lub bezstronności biegłego albo inne ważne powody (art. $196 \S 3$ k.p.k.) oraz w przypadku, gdy opinia jest niepełna, niejasna, wewnętrznie sprzeczna lub gdy zachodzi sprzeczność między różnymi

${ }^{20}$ Dz. U. 2019, poz. 1469. 
opiniami w tej samej sprawie (art. 201 k.p.k.). Dopuszczenie w postępowaniu karnym dowodu $\mathrm{z}$ opinii innego biegłego powiązano tym samym z oceną odnoszącą się do biegłego - w kontekście jego bezstronności (art. 196 k.p.k.) i wiedzy (art. $196 \S 3$ k.p.k.), jak również związaną z treścią jego opinii (art. 201 k.p.k.).

W odniesieniu do opinii psychiatrycznej wprowadzono w kodeksie postępowania karnego dodatkową, samodzielną przesłankę wyłączenia biegłego od opiniowania o stanie zdrowia psychicznego oskarżonego przez osoby pozostające $\mathrm{w}$ związku małżeńskim lub $\mathrm{w}$ innym stosunku, który mógłby wywołać uzasadnioną wątpliwość odnośnie do ich samodzielności (art. 202 $\S 4$ k.p.k. $)^{21}$. Wprawdzie w przepisie tym nie przyjęto, że biegły podlega wyłączeniu, a na jego miejsce powołuje się innego biegłego, ale ratio legis wskazanego rozwiązania nie pozostawia wątpliwości, że skoro dana osoba nie może brać udziału w opiniowaniu (co wynika ze sformułowania „biegli nie mogą...”), to należy powołać innego biegłego, po to aby wydać opinię, o której mowa w art. $202 \S 1$ k.p.k. ${ }^{22}$

Kodeks postępowania karnego posługuje się w art. $196 \S 2$ i 3 pojęciem „innego biegłego”, zaś w art. 201 używa liczby mnogiej - „innych biegłych”. Kodeks postępowania cywilnego w art. 286 używa sformułowania ,innych biegłych". Na tej podstawie - w oparciu na znaczeniu literalnym - nie można uznać, że w przypadkach, o których mowa w art. 196 § 2 i 3 k.p.k. organ procesowy może powołać wyłącznie jednego biegłego, podczas gdy w oparciu na art. 201 k.p.k. i art. 286 k.p.c. niezbędne jest powołanie co najmniej dwóch biegłych. W każdym przypadku organ procesowy podejmuje decyzję, czy powołać jednego biegłego, czy też kilku biegłych (zob. art. $193 \S 1$ k.p.k. i art. $278 \S 1$ k.p.c.), co związane jest z okolicznościami konkretnej sprawy i charakterem uchybień złożonej opinii. W przypadkach, o których mowa $\mathrm{w}$ art. $196 \S 2$ i 3 k.p.k., co do zasady w miejsce wyłączonego biegłego powołany będzie inny biegły, ale nie można wykluczyć, że organ procesowy zdecyduje się na powołanie kilku biegłych, co dotyczyć będzie zwłaszcza sprawy, w której podniesiono wątpliwości odnośnie do wiedzy dotychczasowego biegłego, a stwierdzenie okoliczności mających istotne znaczenie dla rozstrzygnięcia sprawy wymaga szerszego spojrzenia merytorycznego niż dotychczasowe.

\footnotetext{
${ }^{21}$ D. GRusZECKA, [w:] Kodeks postępowania karnego. Komentarz, J. Skorupka, Warszawa: Wolters Kluwer 2015, s. 495.

${ }^{22} \mathrm{Cz}$. KŁAK, Powotanie innego biegłego w polskim procesie karnym. Problematyka oceny dowodu z opinii biegłego w kontekście art. 193, 196, 201 i 202 \& 3 k.p.k., „Problemy współczesnej kryminalistyki” 2006, t. X, s. 120.
} 


\section{DOPUSZCZENIE DOWODU Z OPINII INNEGO BIEGLEGO ZE WZGLĘDU NA WADY DOTYCHCZASOWEJ OPINII}

Art. 286 k.p.c. kwestię dopuszczenia dowodu z opinii innego biegłego wyraźnie łączy z oceną treści dotychczasowej opinii, tj. ze stwierdzeniem jej wadliwości ${ }^{23}$. Z przepisu tego wynika, że „sąd może zażądać ustnego lub pisemnego uzupełnienia opinii lub jej wyjaśnienia, a także dodatkowej opinii od tych samych lub innych biegłych". Samo niezadowolenie strony z treści złożonej opinii nie jest dostateczną podstawą do dopuszczenia dowodu z opinii uzupełniającej (ustnej lub pisemnej) czy też opinii dodatkowej. Uzasadnieniem dla takiej decyzji procesowej winny być należycie umotywowane zarzuty wskazujące niekompletność, nielogiczność i niespójność opinii ${ }^{24}$. Sąd ma obowiązek dopuszczenia dowodu z dalszej opinii, gdy opinia, którą dysponuje, zawiera istotne luki, bo nie odpowiada na postawione tezy dowodowe, jest niejasna, czyli nienależycie uzasadniona lub nieweryfikowalna, $\mathrm{tj}$. gdy przedstawiona przez biegłego analiza nie pozwala organowi orzekającemu skontrolować jego rozumowania co do trafności jego wniosków końcowych ${ }^{25}$.

Usunięciu wątpliwości nasuwających się w związku z treścią opinii służą środki przewidziane w art. 286 k.p.c. Dopiero w przypadku braku możności udzielenia przez biegłego kategorycznej odpowiedzi lub wskazania stopnia prawdopodobieństwa sąd będzie zmuszony ustalić okoliczności, dla wyjaśnienia których powołano biegłego, na podstawie całokształtu zebranego w sprawie materiału dowodowego i przy zastosowaniu ogólnych reguł postępowania dowodowego ${ }^{26}$.

Kodeks postępowania cywilnego nie określa w art. 286, w jakich przypadkach przepis ten znajduje zastosowanie. To w orzecznictwie sformułowano przesłanki ponownego zwrócenia się do dotychczasowych biegłych lub powołania innych. Związane są one $\mathrm{z}$ istotnymi wadami opinii (niezupełność, niejasność, niespójność, nielogiczność, brak należytego uzasadnienia, nieweryfikowalność), jak również potrzebą uzyskania opinii w szerszym zakresie, niż pierwotnie zakładano (dodatkowa opinia tych samych biegłych).

Z przywołanego przepisu wynika, że sąd może zażądać ustnego lub pisemnego uzupełniania opinii, co odnosi się do sytuacji, w której stwierdzono jej niepełność. W takim przypadku biegły składa opinię uzupełniającą. Sąd

\footnotetext{
${ }^{23}$ Wyrok SA w Krakowie z 21 czerwca 2018 r., I ACa 114/18, LEX nr 2545097.

${ }^{24}$ Wyrok SA w Lublinie z 31 lipca 2019 r., III AUa 317/19, LEX nr 2706237.

${ }^{25}$ Wyrok SA w Gdańsku z 14 listopada 2018 r., V ACa 16/18, LEX nr 2638969.

${ }^{26}$ Wyrok SN z 19 września 2018 r., I CSK 578/17, LEX nr 2566916.
} 
może również zażądać ustnego lub pisemnego wyjaśnienia złożonej opinii, co związane jest np. z wątpliwościami dotyczącymi przywołanej literatury fachowej (naukowej lub technicznej), zakresu przeprowadzonych badań, kryteriów wyboru metody badawczej itp. Sąd może także zażądać dodatkowej opinii od tych samych biegłych, co związane jest $\mathrm{z}$ rozszerzeniem zakresu opiniowania. W tym przypadku nie musi być to związane $\mathrm{z}$ wadą poprzedniej opinii, lecz może wynikać np. z konieczności zasięgnięcia opinii w szerszym zakresie, w tym w związku z nowymi ustaleniami faktycznymi. Dodatkowa opinia może być jednak uzasadniona wadą opinii poprzedniej, jeżeli powołany biegły niezasadnie pominął określone okoliczności (zagadnienia, problemy), bez analizy których nie jest możliwe sformułowanie kategorycznych i przekonujących wniosków końcowych. $Z$ tego punktu widzenia będzie to opinia niepełna, ale jej uzupełnienie $\mathrm{w}$ istocie będzie polegało na złożeniu - w tym zakresie - opinii dodatkowej, w sytuacji, gdy poprzednia opinia w ogóle nie odnosiła się do tych kwestii. Jak wskazano w piśmiennictwie, w takim przypadku dodatkowa opinia służyć ma wyjaśnieniu wad złożonej opinii ${ }^{27}$. Na podstawie art. 286 k.p.c. sąd może także zażądać opinii od innych biegłych, przy czym ustawa procesowa nie preferuje wariantu dopuszczenia dowodu z opinii innych biegłych. Oba warianty (zwrócenie się do dotychczasowych biegłych, dopuszczenie dowodu z opinii innych biegłych) są - z procesowego punktu widzenia - równorzędne. Wybór w tym zakresie zależy od uznania sądu ${ }^{28}$.

Jak trafnie wskazano w orzecznictwie, o ewentualnym dopuszczeniu dowodu z opinii innego biegłego tej samej specjalności nie może decydować wyłącznie wniosek strony, lecz zawarte w tym wniosku konkretne uwagi i argumenty podważające miarodajność dotychczasowej opinii lub co najmniej miarodajność tę poddające $\mathrm{w}$ wątpliwość. W przeciwnym wypadku wniosek taki musi być uznany za zmierzający wyłącznie do nieuzasadnionej zwłoki w postępowaniu, co winno skutkować jego pominięciem ${ }^{29}$.

Konieczność dopuszczenia dowodu z opinii kolejnego biegłego istnieje wówczas, gdy występuje rozbieżność, niezupełność lub niejasność opinii albo gdy materiał dowodowy nie daje podstawy do oparcia się wyłącznie na opinii jednego biegłego bądź tylko na jednej opinii tego samego biegłego ${ }^{30}$.

\footnotetext{
${ }^{27}$ M. CiCHORSKA, [w:] Kodeks postępowania cywilnego. Koszty sądowe w sprawach cywilnych. Dochodzenie roszczeń w postępowaniu grupowym. Przepisy przejściowe, t. I, red. T. Zembrzuski, Warszawa: Wolters Kluwer 2020, teza 6 do art. 286.

${ }^{28}$ T. ERECIŃSKI, Komentarz do kodeksu, s. 567.

${ }^{29}$ Wyrok SA w Warszawie z 19 września 2019 r., I ACa 483/18, LEX nr 2728639.

${ }^{30}$ Wyrok SA w Białymstoku z 28 lutego 2019 r., I ACa 792/18, LEX nr 2741655.
} 
Ze stanowiskiem tym koresponduje pogląd, że potrzeba zażądania dodatkowej opinii od innego biegłego zachodzi wówczas, gdy dotychczasowa opinia zawiera istotne braki, nie wyjaśnia okoliczności ${ }^{31}$, a zdaniem sądu nie jest możliwe ich usunięcie czy też wyjaśnienie istotnych okoliczności poprzez zwrócenie się do dotychczasowych biegłych o opinię uzupełniającą lub dodatkową.

W świetle art. 286 k.p.c. nie można przyjąć, że sąd jest zobowiązany dopuścić dowód z kolejnych biegłych w każdym przypadku, gdy złożona opinia jest niekorzystna dla strony. W takiej sytuacji sąd byłby wszakże zobligowany do uwzględnienia także kolejnych wniosków strony dopóty, dopóki niezłożona zostałaby opinia w pełni ją zadowalająca, co jest niedopuszczalne. Potrzeba powołania innego biegłego powinna więc wynikać z okoliczności sprawy, a nie z samego niezadowolenia strony z dotychczas złożonej opinii. Powinna ona być następstwem umotywowanej krytyki dotychczasowej opinii, a nie wynikać z przeświadczenia strony, że dalsze opinie pozwolą na udowodnienie korzystnej dla strony tezy ${ }^{32}$. W piśmiennictwie i orzecznictwie wskazano, że sąd ma obowiązek przeprowadzenia dowodu z opinii dalszych (innych) biegłych, gdy złożona opinia nie pozwala organowi orzekającemu na zweryfikować zawartego w niej rozumowania, co do trafności wniosków końcowych, a także, gdy opinie biegłych są rozbieżne, a sąd nie może się oprzeć tylko na jednej z nich ${ }^{33}$.

W postępowaniu karnym art. 201 k.p.k. określa, w jakich przypadkach organ procesowy władny jest „wezwać ponownie tych samych biegłych lub powołać innych”. Jest to możliwe w przypadku, gdy złożona opinia biegłego jest niepełna lub niejasna albo gdy zachodzi sprzeczność w samej opinii lub między różnymi opiniami $\mathrm{w}$ tej samej sprawie. $\mathrm{Z}$ ustawy procesowej wyraźnie wynika zatem, jakie są przesłanki zastosowania tego przepisu. Zestawienie art. 201 k.p.k. z art. 286 k.p.c. uzasadnia wniosek, że kodeks postępowania karnego precyzyjnie określa, kiedy możliwe jest zwrócenie się o sporządzenie opinii uzupełniającej do dotychczasowych biegłych lub powołanie innych. W postępowaniu cywilnym przesłanki te zostały sformułowane w orzecznictwie. Nie ma natomiast różnicy między wskazanymi przepisami odnośnie do sposobu reakcji na stwierdzoną wadliwość złożonej opinii. Także bowiem

\footnotetext{
${ }^{31}$ Wyrok SA w Białymstoku z 17 maja 2018 r., III APa 3/18, LEX nr 2546188.

${ }^{32}$ Wyrok SA w Białymstoku z 25 lipca 2018 r., I ACa 129/18, LEX nr 2627840.

${ }^{33}$ J. DZIERŻANOWSKA, J. STUDZIŃSKA, Komentarz do niektórych przepisów kodeksu postępowania cywilnego, [w:] TYCHŻE, Biegli w sadowym postępowaniu cywilnym i karnym. Praktyczne omówienie regulacji z orzecznictwem, Warszawa: Wolters Kluwer 2019, teza 3 do art. 286.
} 
z art. 201 k.p.k. wynika, że organ procesowy ma dwie możliwości reakcji ponowne wezwanie tych samych biegłych lub powołanie innych biegłych, przy czym wybór należy do tego organu ${ }^{34}$, a ustawa nie preferuje żadnego z możliwych rozwiązań ${ }^{35}$, tj. są one równoważne ${ }^{36}$.

W świetle powyższych uwag podzielić należy pogląd, że zgodnie z regulacją art. 201 k.p.k., powołanie nowego zespołu biegłych celem opiniowania okoliczności objętych opinią już wcześniej wydaną jest dopuszczalne wyłącznie przy wykazaniu takich wad dotychczasowej opinii, o jakich mowa w tym przepisie. Tym samym jest to zasadne wyłącznie w sytuacji, gdyby dotychczasowa opinia okazała się niepełna, niejasna albo dotknięta sprzecznością, przy czym wskazany przepis nawet w przypadku stwierdzenia tego rodzaju wadliwości opinii przewiduje dwojaki sposób rozwiązania problemu jej niejasności, niepełności czy sprzeczności, pozostawiając decyzję, co do wyboru metody organowi procesowemu przeprowadzającemu postępowanie dowodowe ${ }^{37}$. O tym, które $\mathrm{z}$ tych rozwiązań wybrać, decydują okoliczności konkretnej sprawy ${ }^{38}$.

W orzecznictwie sformułowano trafny pogląd, że powołanie innych biegłych na podstawie art. 201 k.p.k. powinno nastąpić wówczas, gdy sąd (organ procesowy - podkreślenie Cz.P.K.) sam nie będzie w stanie rozstrzygnąć wątpliwości związanych z niejasną czy niepełną opinią dotychczasowych biegłych ${ }^{39}$. Powołanie innych biegłych na podstawie art. 201 k.p.k. jest również konieczne wówczas, gdy sąd (organ procesowy - podkreślenie Cz.P.K.), kierując się zasadą swobodnej oceny dowodów, nie jest w stanie wyjaśnić sprzeczności występujących między różnymi opiniami ${ }^{40}$, przy czym w praktyce orzeczniczej przyjmuje się, że w razie rozbieżności opinii, gdy nie usunęły ich zeznania biegłych, należy żądać, by skonfrontowani biegli ustosunkowali się do opinii przeciwnych, wskazując na ich ewentualne błędy lub braki, a zaniechanie przeprowadzenia tej czynności może w pewnych sytuacjach procesowych rażąco naruszać przepisy postępowania i wpływać na treść wyroku ${ }^{41}$. Wynika $\mathrm{z}$ tego, że $\mathrm{w}$ praktyce przyjmuje się, że racjonalne

\footnotetext{
${ }^{34}$ Wyrok SN z 3 marca 2014 r., WA 30/13, LEX nr 1460571.

${ }^{35}$ T. GrZEgORCZYK, Kodeks postępowania karnego oraz ustawa o świadku koronnym. Komentarz, Warszawa: Lex 2008, s. 466.

${ }^{36}$ Wyrok SA we Wrocławiu z 9 kwietnia 2014 r., II AKa 70/14, LEX nr 1459125.

${ }^{37}$ Wyrok SA w Warszawie z 20 października 2017 r., II AKa 306/17, LEX nr 2402456.

${ }^{38}$ Postanowienie SN z 27 lipca 2016 r., V KK 25/16, LEX nr 2108096.

${ }^{39}$ Wyrok SN z 11 marca 2014 r., WA 1/14, LEX nr 1444408.

${ }^{40}$ Wyrok SN z 28 sierpnia 2013 r., V KK 80/13, LEX nr 1381068.

${ }^{41}$ Wyrok SA w Krakowie z 10 listopada 2012 r., II AKa 107/12, LEX nr 1293419.
} 
jest, aby w pierwszej kolejności wątpliwości wyjaśnione zostały poprzez wezwanie ponowne dotychczasowego biegłego (biegłych), w tym przez jego (ich) przesłuchanie i ewentualnie konfrontację, a dopiero w następnej kolejności - gdy nie zostaną one wyjaśnione mimo podjęcia takich czynności poprzez powołanie innego (innych) biegłego (biegłych). Nie zawsze będzie to uzasadnione, gdyż istotne wady opinii mogą dyskwalifikować biegłego (biegłych), który (którzy) ją (je) złożył (złożyli), a to może przemawiać za koniecznością powołania innego biegłego (biegłych), bez uprzedniego wezwania dotychczasowego biegłego (biegłych).

\section{DOPUSZCZENIE DOWODU Z OPINII INNEGO BIEGŁEGO ZE WZGLĘDU NA WYSTĄPIENIE PODSTAW DO WYŁĄCZENIA DOTYCHCZASOWEGO BIEGŁEGO}

Kodeks postępowania cywilnego nie przewiduje formalnie możliwości powołania innego biegłego ze względu na okoliczności odnoszące się do osoby dotychczasowego biegłego - w tym jego bezstronności i wiedzy, tak jak to uczyniono w art. $196 \S 2$ i 3 k.p.k. W kodeksie postępowania karnego wyraźnie przyjęto, że w przypadku wyłączenia biegłego, ze względu na wystąpienie okoliczności, o których mowa w tych przepisach, powołuje się innego biegłego. Wprawdzie w kodeksie postępowania cywilnego uregulowano instytucję wyłączenia biegłego (art. 281), niemniej jednak nie przyjęto expressis verbis rozwiązania, że wyłączenie biegłego w toku postępowania skutkuje koniecznością powołania innego biegłego, jak to ma miejsce w art. $196 \S 2$ i 3 k.p.k. Najwyraźniej ustawodawca uznał, że jest to oczywiste, skoro bowiem dochodzi do wyłączenia biegłego, a zachodzi wypadek wymagający wiadomości specjalnych (art. $278 \S 1$ k.p.c.), to w miejsce wyłączonego należy powołać innego biegłego, tak, aby sąd uzyskał wymagany dowód $\mathrm{z}$ opinii biegłego. Jak trafnie przyjęto w orzecznictwie, specyfika dowodu z opinii biegłego wiąże się z tym, że okoliczności faktyczne wymagające wiedzy specjalnej nie mogą być zastąpione innymi środkami dowodowymi ${ }^{42}$. Ustalenia wymagające wiadomości specjalnych, aby mogły stać się składnikiem materiału dowodowego poddanego ocenie, muszą przybrać formę określoną w art. 278 i następne k.p.c., to znaczy postać opinii biegłego (biegłych)

\footnotetext{
${ }^{42}$ Wyrok SA w Krakowie z 13 czerwca 2019 r., I ACa 366/18, LEX nr 2780936; wyrok SA w Krakowie z 5 czerwca 2019 r., I ACa 87/19, LEX nr 2784445.
} 
lub odpowiedniego instytutu ${ }^{43}$. Tym samym wyłączenie dotychczasowego biegłego oznacza, że należy powołać innego biegłego (inny instytut) w celu zasięgnięcia jego opinii, albowiem jeżeli do poczynienia ustaleń istotnych dla rozstrzygnięcia sprawy potrzebne są wiadomości specjalne, sąd nie może dokonać ich sam, nawet gdyby miał w tej dziedzinie odpowiednie kwalifikacje merytoryczne ${ }^{44}$. Innymi słowy, jeżeli dana okoliczność jest relewantna z punktu widzenia mających zastosowanie w sprawie przepisów prawa materialnego, powinna zostać ustalona w postępowaniu sądowym przez sąd po zasięgnięciu opinii biegłego (biegłych), zgodnie z art. 278 § 1 k.p.c. ${ }^{45}$ Sąd musi w zakresie wymagającym wiedzy specjalnej posłużyć się specyficznym dowodem, jakim jest opinia biegłego ${ }^{46}$. Opinia biegłego zgodnie z art. 278 $\S 1$ k.p.c. służy stworzeniu sądowi możliwości prawidłowej oceny materiału procesowego w wypadkach, kiedy ocena ta wymaga wiadomości specjalnych w rozumieniu powyższego przepisu (a więc zasobu wiadomości wykraczających poza zakres wiedzy powszechnej). Zadaniem biegłego zasadniczo nie jest poszukiwanie dowodów i okoliczności mających uzasadniać argumentację stron procesu, lecz dokonanie oceny przedstawionego materiału z perspektywy posiadanej wiedzy naukowej, technicznej lub branżowej i przedstawienie sądowi danych (wniosków) umożliwiających poczynienie właściwych ustaleń faktycznych i prawidłowej oceny prawnej znaczenia zdarzeń, z których strony wywodzą swoje racje ${ }^{47}$. Tym samym, dowód $z$ opinii biegłego dostarczyć ma sądowi wiedzy niezbędnej dla właściwej oceny materiału procesowego przedstawionego przez strony ( $\mathrm{w}$ tym zwłaszcza innych dowodów) $\mathrm{z}$ perspektywy odpowiedniej dziedziny nauki lub techniki ${ }^{48}$. Dowód taki w postępowaniu cywilnym jest jedyną drogą pozyskania koniecznych do rozstrzygnięcia wiadomości specjalnych i nie może być zastąpiony inną czynnością dowodową ${ }^{49}$. Innymi słowy, okoliczności wymagające wiedzy specjalistycznej w toku postępowania cywilnego ustalane mogą być jedynie w drodze opinii biegłego ${ }^{50}$. Do naruszenia art. $278 \S 1$ k.p.c. może dojść wtedy, gdy sąd samodzielnie wypowiada się w kwestiach wymagających

\footnotetext{
${ }^{43}$ Wyrok SA w Białymstoku z 29 maja 2019 r., I ACa 797/18, LEX nr 2713669.

${ }^{44}$ K. Flaga-GierusZyńsKa, [w:] K. Flaga-GierusZyńSKA, M. ZielińSKi, Kodeks postępowania cywilnego. Komentarz, Warszawa: C.H. Beck 2019, s. 583.

${ }^{45}$ Wyrok SN z 12 kwietnia 2019 r., I CSK 166/18, LEX nr 2647531.

${ }^{46}$ Wyrok SA w Warszawie z 3 sierpnia 2018 r., V ACa 546/17, LEX nr 2697349.

${ }^{47}$ Wyrok SA w Szczecinie z 12 marca 2019 r., I ACa 785/16, LEX nr 2668080.

${ }^{48}$ Wyrok SA w Szczecinie z 27 lutego 2019 r., I ACa 449/18, LEX nr 2668147.

${ }^{49}$ Wyrok SA w Białymstoku z 28 lutego 2019 r., I ACa 49/18, LEX nr 2728131.

${ }^{50}$ Wyrok SA w Gdańsku z 31 sierpnia 2018 r., V ACa 728/17, LEX nr 2629005.
} 
wiadomości specjalnych, z pominięciem dowodu z opinii biegłego ${ }^{51}$. Jeżeli zgodnie $\mathrm{z}$ art. $278 \S 1$ k.p.c. - sąd może otrzymać wiadomości specjalne wyłącznie na skutek skorzystania $z$ pomocy biegłego, to sąd dopuszcza się naruszenia art. 232 zd. 2 k.p.c., jeśli z urzędu nie przeprowadza dowodu z opinii biegłego, który jest niezbędny dla właściwej oceny zasadności wytoczonego powództwa ${ }^{52}$. Do naruszenia art. 232 zd. 2 k.p.c. dochodzi zatem, gdy dowód $z$ opinii biegłego jest niezbędny, a mimo to sąd takiej czynności nie podejmuje ${ }^{53}$. Logiczne jest więc, że następstwem wyłączenia dotychczasowego biegłego jest obowiązek powołania w jego miejsce innego biegłego. Nadal bowiem do poczynienia ustaleń faktycznych dla rozstrzygnięcia sprawy niezbędne są wiadomości specjalne, a tymi dysponuje tylko biegły właściwej specjalności, zaś dowód z opinii biegłego ma dostarczyć sądowi wiedzy niezbędnej dla prawidłowej oceny materiału procesowego przedstawionego przez strony (w tym zwłaszcza innych dowodów) z perspektywy odpowiedniej dziedziny nauki lub techniki ${ }^{54}$. Sąd z braku wiadomości specjalnych nie jest uprawniony do dokonywania odpowiednich ustaleń bez zasięgnięcia opinii biegłego, toteż właściwym środkiem dowodowym służącym wyjaśnieniu tych okoliczności może być tylko dowód z opinii biegłego (art. 278 k.p.c.) ${ }^{55}$.

Powyższe założenie, że skutkiem wyłączenia biegłego jest konieczność powołania innego biegłego, pozostaje w łączności z tym, które występuje na gruncie art. $202 \S 4$ k.p.k., w którym także wyłączenia biegłego nie powiązano wyraźnie z powołaniem innego biegłego, ale wyłączenie biegłego na tej podstawie skutkuje koniecznością powołania innego biegłego (innych biegłych), co jest następstwem rozwiązania przyjętego w art. $202 \S 1$ k.p.k.

Nie ulega wątpliwości, że biegły w postępowaniu cywilnym ${ }^{56}$, tak jak w postępowaniu karnym ${ }^{57}$, zobowiązany jest do zachowania bezstronności. W orzecznictwie na gruncie kodeksu postępowania cywilnego podkreślono, że skoro rolą biegłego jest udzielenie wsparcia sądowi orzekającemu w obo-

\footnotetext{
${ }^{51}$ Wyrok SN z 24 października 2018 r., II CSK 623/17, LEX nr 2567918; wyrok SA w Warszawie z 5 marca 2019 r., III AUa 956/17, LEX nr 2704894.

${ }^{52}$ Wyrok SN z 15 lutego 2019 r., II CSK 723/17, LEX nr 2621120.

${ }^{53}$ Wyrok SA w Białymstoku z 31 stycznia 2019 r., I ACa 673/18, LEX nr 2630430.

${ }^{54}$ Wyrok SA w Szczecinie z 28 marca 2019 r., I ACa 612/18, LEX nr 2668049.

${ }^{55}$ Wyrok SA w Poznaniu z 23 sierpnia 2018 r., I ACa 1495/17, LEX nr 2582655.

${ }^{56}$ M.in. wyrok SN z 20 maja 2014 r., I UK 427/13, LEX nr 1511380; wyrok SA w Łodzi z 5 czerwca 2018 r., I AGa 167/18, LEX nr 2571390; wyrok SA w Lodzi z 30 listopada 2018 r., I ACa 1736/17, LEX nr 2625568.

${ }^{57}$ M.in. K. PAPKE-OLSZAuSKas, Wyłaczenie uczestników procesu karnego, Gdańsk: Wydawnictwo Uniwersytetu Gdańskiego 2007, s. 238-241.
} 
wiązku wszechstronnego i rzetelnego zbadania sprawy i skoro na tle innych osobowych środków dowodowych dowód z opinii biegłego wyróżnia specjalny jego przedmiot, cel, charakter oraz specyficzne, właściwe tylko jemu, kryteria oceny, to aby dowód taki był pełnowartościowy i przydatny dla orzekania, biegły musi sporządzać opinię w sposób rzetelny i niebudzący żadnych wątpliwości co do braku istnienia jakichkolwiek powiązań czy więzów osobistych dotyczących podmiotu podlegającego ocenie ${ }^{58}$. Stanowisko to koresponduje $\mathrm{z}$ rozumieniem bezstronności biegłego na gruncie kodeksu postępowania karnego, gdzie wskazano, że opinia wydana przez biegłego stronniczego (subiektywnie i obiektywne) nie stanowi dowodu w sprawie, a w miejsce tego biegłego należy powołać innego (art. $196 \S 3$ k.p.k.) ${ }^{59}$.

W świetle powyższych uwag nie może ulegać wątpliwości, że bezstronność biegłego jest jednym z kryteriów oceny jego opinii, a jej niezachowanie może być podstawą do powołania innego biegłego, w miejsce biegłego, który podlega wyłączeniu. Odróżnić przy tym należy dwa przypadki. Jeżeli zostanie złożony wniosek na podstawie art. 281 k.p.c. w zw. z art. 49 k.p.c. i wystąpi podstawa do wyłączenia biegłego, ze względu na istnienie okoliczności tego rodzaju, że mogłaby wywołać uzasadnioną wątpliwość co do jego bezstronności w danej sprawie, to powołanie innego biegłego związane będzie $\mathrm{z}$ wyłączeniem biegłego dotychczasowego, zaś jego opinia nie będzie stanowiła dowodu w sprawie - w świetle wyroku Sądu Najwyższego z 27 maja 1976 r. Jeżeli natomiast zachodzić będą takie okoliczności, ale wniosek strony nie zostanie złożony, w wyniku czego nie zostanie zastosowany art. 281 k.p.c. w zW. z art. 49 k.p.c., nic nie stoi na przeszkodzie uwzględnieniu tej okoliczności w ramach sędziowskiej oceny wiarygodności i mocy dowodowej na podstawie art. $233 \S 1$ k.p.c. ${ }^{60}$ Sąd we wskazanym przypadku władny jest wyjaśnić wątpliwości co do bezstronności biegłego na podstawie art. 286 k.p.c., a jeżeli wątpliwości we wskazanym zakresie nie zostaną wyjaśnione, podstawą powołania innego biegłego będzie właśnie ten przepis, wątpliwości odnoszące się do braku bezstronności biegłego (które nie zostały wyjaśnione) rzutują bowiem na jej walor dowodowy. Mogą być zatem wyjaśniane na jego podstawie. Przyjętej wykładni nie podważa brzmienie art. 286 k.p.c., w którym jest mowa o „uzupełnieniu opinii lub jej wyjaśnieniu”. Ustawa procesowa nie wyklucza bowiem wyjaśnienia wątpliwości odnoszących

\footnotetext{
${ }^{58}$ Wyrok SA w Warszawie z 26 kwietnia 2019 r., I ACa 88/17, LEX nr 2753901.

${ }^{59}$ Wyrok SA we Wrocławiu z 5 grudnia 2018 r., II AKa 181/18, LEX nr 2609436; wyrok SA we Wrocławiu z 6 października 2017 r., II AKa 233/17, LEX nr 2412867.

${ }^{60}$ K. FLAGA-GIERUSZYŃSKA, Kodeks postepowania cywilnego, s. 588.
} 
się do samego biegłego w kontekście złożonej przez niego opinii (w tym finalnych wniosków), a może być to niezbędne do dokonania jej prawidłowej oceny. „Wyjaśnienia” opinii, o którym mowa w art. 286 k.p.c., nie powiązano $\mathrm{w}$ ustawie procesowej wyłącznie $\mathrm{z}$ kwestiami merytorycznymi, związanymi z jej treścią, co stwarza możliwość szerokiego rozumienia tego pojęcia, nie wyłączając kwestii bezstronności biegłego, wszakże jest to okoliczność o istotnym znaczeniu dla wiarygodności samej opinii i dokonania jej oceny na podstawie art. $233 \S 1$ k.p.c.

Kodeks postępowania karnego wprost łączy powołanie innego biegłego z oceną wiedzy dotychczasowego biegłego (art. 196 § 3 k.p.k.). Jak wskazano w piśmiennictwie, w przypadku okoliczności odnoszących się do wiedzy biegłego chodzi o wykazanie, że zakres tej wiedzy nie spełnia wymogów określonych w art. 193 k.p.k., co dotyczy sytuacji, w której biegły nie jest w stanie poprzeć swych twierdzeń właściwą argumentacją, odwołuje się do metod badawczych uznanych $\mathrm{w}$ literaturze fachowej za mało wiarygodne, a jednocześnie nie zna metodologii powszechnie uznanej za prawidłową ${ }^{61}$. Co istotne, wprawdzie art. $196 \S 3$ k.p.k. określa samoistną podstawę do powołania innego biegłego, niemniej jednak „ujawnienie się powodów osłabiających zaufanie do wiedzy biegłego" może wynikać - i tak też będzie najczęściej - ze złożonej przez niego opinii. W ramach oceny dowodu z opinii biegłego analiza obejmuje m.in. fachowość biegłego, poprawność i sposób dokonania czynności badawczych, jak również przyjęte metody badawcze ${ }^{62}$, co mieści się w zakresie oceny „wiedzy biegłego”. Nie można wykluczyć, że powody te doprowadzą do wadliwości samej opinii w rozumieniu art. 201 k.p.k. Podzielić należy pogląd T. Widły, że dopiero w toku lektury opinii lub przesłuchania biegłego decydent nader często może nabrać wątpliwości odnośnie do „fachowych kwalifikacji biegłego"63. Tytułem przykładu należy wskazać, że posługiwanie się przez biegłego w jego opinii nielogiczną argumentacją prowadzić może zarówno do osłabienia zaufania do wiedzy biegłego - braki w zakresie umiejętności argumentowania dowodzić mogą braku odpowiedniej wiedzy, jak też przesądzić o niejasności opinii w rozumieniu art. 201 k.p.k., a ta występuje m.in. w sytuacji, gdy argumentacja zawarta w opinii jest nie-

\footnotetext{
${ }^{61}$ M. KUROwSKI, [w:] Kodeks postepowania karnego. Komentarz, t. I, red. D. Świecki, Warszawa: Wolters Kluwer 2013, s. 636 i cytowane tam piśmiennictwo oraz orzecznictwo.

${ }^{62}$ T. TOMASZEwSKi, Dowód z opinii biegłego w procesie karnym, Kraków: Wydawnictwo Instytutu Ekspertyz Sądowych 2000, s. 76 - 77.

${ }^{63}$ T. WIDŁA, Ocena dowodu z opinii biegłego, Katowice: Uniwersytet Śląski 1992, s. 36.
} 
logiczna ${ }^{64}$. W takim przypadku podstawa powołania innego biegłego będzie złożona, łącząc przesłankę z art. $196 \S 3$ k.p.k. i art. 201 k.p.k.

$\mathrm{Na}$ gruncie kodeksu postępowania cywilnego wiedza biegłego oceniana jest w ramach badania fachowości opinii, na co trafnie zwróciły uwagę J. Dzierżanowska i J. Studzińska w swym artykule (na s. 31). Również w orzecznictwie sądowym nie budzi wątpliwości fakt, że opinia biegłego może być oceniana pod względem fachowości jej sporządzenia i rzetelności ${ }^{65}$, zaś wyjaśnienie wątpliwości w tym zakresie odbywa się w ramach procedury, o której mowa w art. 286 k.p.c. Mimo zatem braku wyraźnego przepisu procesowego, braki w zakresie wiedzy, ujawnione w wyniku analizy złożonej przez biegłego opinii, mogą być podstawą do jej zdyskwalifikowania i finalnie dopuszczenia dowodu $\mathrm{z}$ opinii innego biegłego na podstawie art. 286 k.p.c. Oczywiste jest, że opinia biegłego oceniana jak inne dowody, według art. 233 $\S 1$ k.p.c., weryfikowana jest na podstawie szczególnych kryteriów, do których należy m.in. poziom wiedzy biegłego ${ }^{66}$. Nie chodzi tu przy tym o dokonanie oceny przedstawionych poglądów naukowych lub dotyczących wiedzy specjalistycznej (naukowej lub technicznej) ${ }^{67}$, lecz o sprawdzenie, czy jest to wiedza aktualna, uwzględniająca dorobek nauki lub techniki w danym obszarze, jak również, czy przyjęte przez biegłego podstawy metodologiczne są prawidłowe ${ }^{68}$. Ocena dowodu $\mathrm{z}$ opinii biegłego $\mathrm{z}$ punktu widzenia sposobu motywowania stanowiska przez biegłych, jak również podstaw teoretycznych

\footnotetext{
${ }^{64}$ E. HABZDA-SiweK, Diagnoza stanu psychicznego sprawcy a rozstrzygnięcia $w$ procesie karnym, Kraków: Zakamycze 2002, s. 50; wyrok SA w Warszawie z 9 października 2019 r., II AKa 148/19, LEX nr 2750301.

${ }^{65}$ Wyrok SA w Lublinie z 27 listopada 2019 r., III AUa 617/19, LEX nr 2758369; wyrok SA w Lublinie z 9 maja 2019 r., III AUa 307/18, LEX nr 2679335; wyrok SA w Gdańsku z 14 stycznia 2019 r., V AGa 138/18, LEX nr 2673410; wyrok SA w Szczecinie z 9 stycznia 2019 r., I ACa 689/18, LEX nr 2668037; wyrok SA w Lublinie z 10 października 2018 r., III AUa 195/18, LEX nr 2574809.

${ }^{66}$ Wyrok SA w Gdańsku z 13 listopada 2019 r., V ACa 518/19, LEX nr 2797440; wyrok SA w Białymstoku z 10 października 2019 r., III AUa 272/19, LEX nr 2781357; wyrok SA w Szczecinie z 3 października 2019 r., I ACa 459/19, LEX nr 2771942; wyrok SA w Szczecinie z 24 września 2019 r., I ACa 403/19, LEX nr 2770874; wyrok SA w Gdańsku z 24 maja 2019 r., V AGa 224/18, LEX nr 2702646; wyrok SA w Krakowie z 16 kwietnia 2019 r., I AGa 479/18, LEX nr 2777802; wyrok SA w Lublinie z 27 marca 2019 r., III AUa 759/18, LEX nr 2669287; wyrok SA w Gdańsku z 28 lutego 2019 r., V AGa 199/18, LEX nr 2696112; wyrok SA w Białymstoku z 3 grudnia 2018 r., I ACa 507/18, LEX nr 2627851; wyrok SA w Szczecinie z 13 listopada 2018 r., III AUa 343/18, LEX nr 2729123; wyrok SA w Lublinie z 1 sierpnia 2018 r., III AUa 1074/17, LEX nr 2534791.

${ }^{67}$ Wyrok SA w Szczecinie z 20 września 2019 r., I ACa 395/18, LEX nr 2728623; wyrok SA w Szczecinie z 22 maja 2019 r., I ACa 751/18, LEX nr 2704181.

${ }^{68}$ Wyrok SA w Szczecinie z 27 listopada 2018 r., I ACa 692/16, LEX nr 2624150.
} 
opinii, co jest dopuszczalne w ramach art. $233 \S 1$ k.p.c. ${ }^{69}$, także prowadzić będzie do oceny poziomu wiedzy biegłego, w jej ramach bowiem sąd kontroluje merytoryczne przygotowanie biegłego do sporządzenia opinii. Jak trafnie przyjęto w orzecznictwie, przy kontroli dowodu z opinii biegłego istotną rolę odgrywa stopień zaufania do wiedzy reprezentowanej przez niego ${ }^{70}$. Co istotne - sąd, zlecając biegłemu wydanie opinii, musi mieć na względzie to, czy dysponuje on wiadomościami specjalnymi niezbędnymi dla stwierdzenia okoliczności mających istotny wpływ dla rozstrzygnięcia sprawy. Wiadomości specjalne mogą wynikać zarówno z przygotowania teoretycznego, jak i wykonywanej w danej dziedzinie pracy i nabytych stąd umiejętności oceny występujących tam zagadnieńn ${ }^{71}$. Już zatem przy dopuszczaniu dowodu z opinii biegłego należy dokonać oceny jego wiedzy (ocena wstępna, aprioryczna), a finalnie dokonać sprawdzenia jej poziomu w kontekście sporządzonej opinii (ocena następcza, aposterioryczna). Jak trafnie wskazano w orzecznictwie, sąd w odniesieniu do dowodu z opinii biegłego ma obowiązek ocenić, czy dowód ten ze względu na swoją treść, zakres, poziom merytoryczny, przyjętą przez biegłego metodologię, kompletność odniesienia się do zgromadzonego materiału dowodowego i zastosowane na jego podstawie założenia, jest dowodem przydatnym dla rozstrzygnięcia sprawy ${ }^{72}$. Nie może zatem ulegać wątpliwości, że dokonując oceny opinii biegłego, sąd w postępowaniu cywilnym ocenia także merytoryczne przygotowanie biegłego do sporządzenia opinii (a więc poziom jego wiedzy), dowód z opinii biegłego musi być bowiem poprawny merytorycznie ${ }^{73}$, przy czym w przypadku, w którym pojawią się w tej materii wątpliwości, ich wyjaśnienie następuje w trybie art. 286 k.p.c.

$\mathrm{Na}$ gruncie art. 281 k.p.c. Sąd Najwyższy przyjął, że opinia biegłego, który został w sprawie po złożeniu opinii wyłączony, winna być uznana za niebyłą na wzór dowodów przeprowadzonych w postępowaniu, które zostało zniesione. W konsekwencji opinia ta nie stanowi żadnego dowodu w spra$w_{i}{ }^{74}$. Skutek ten nie wynika wyraźnie $\mathrm{z}$ treści tego przepisu, niemniej jednak

\footnotetext{
${ }^{69}$ Wyrok SA w Lublinie z 11 września 2019 r., III AUa 40/19, LEX nr 2724215; wyrok SA w Warszawie z 7 sierpnia 2019 r., V ACa 587/18, LEX nr 2726862; wyrok SA w Białymstoku z 28 listopada 2018 r., I ACa 522/18, LEX nr 2691738.

${ }^{70}$ Wyrok SA w Krakowie z 4 lipca 2019 r., I ACa 814/18, LEX nr 2799256.

${ }^{71}$ Wyrok SA w Warszawie z 13 maja 2019 r., I ACa 1478/15, LEX nr 2680704; wyrok SA w Warszawie z 28 września 2018 r., I ACA 467/17, LEX nr 2581364.

${ }^{72}$ Wyrok SA w Warszawie z 24 stycznia 2019 r., VII AGa 606/18, LEX nr 2725368.

${ }^{73}$ Wyrok SA w Łodzi z 6 września 2018 r., I ACa 1759/17, LEX nr 2596528.

${ }^{74}$ Wyrok SN z 27 maja 1976 r., I PR 64/76, LEX nr 7830.
} 
pogląd ten należy podzielić, jeżeli bowiem dana osoba podlega jako biegły wyłączeniu na podstawie art. 281 k.p.c., to jej opinia nie może stanowić dowodu z opinii biegłego, ten pochodzić może bowiem wyłącznie od biegłego, który spełnia warunki określone w tym przepisie, a odnoszące się do jego bezstronności. Innymi słowy, w postępowaniu cywilnym wyłączenie biegłego na podstawie art. 281 k.p.c. eliminuje złożoną przez niego opinię z materiału dowodowego $\mathrm{w}$ danej sprawie (czyli nie jest ona zaliczana do takiego materiału), co z kolei determinuje powołanie innego biegłego w miejsce dotychczasowego. Nadal bowiem poczynienie prawidłowych ustaleń faktycznych - istotnych dla rozstrzygnięcia sprawy - wymaga wiadomości specjalnych, co rodzi obowiązek dopuszczenia dowodu z opinii biegłego. Podkreślić należy, że utrata mocy dowodowej opinii wydanej w postępowaniu karnym przez biegłego wyłączonego na podstawie art. $196 \S 2$ k.p.k. wprost wynika $\mathrm{z}$ ustawy ${ }^{75}$, co oznacza, że w odniesieniu do postępowania cywilnego to Sąd Najwyższy przesądził o procesowych skutkach wyłączenia biegłego (uznanie opinii za niebyłą). Powinny one jednak wyraźnie wynikać ustawy, tak jak ma to miejsce w postępowaniu karnym. Rozwiązanie przyjęte kodeksie postępowania karnego powinno zatem być recypowane na grunt postępowania cywilnego, przy czym wskazać należy, że ustawodawca inaczej uregulował skutki procesowe w przypadku zaistnienia podstaw do bezwzględnego wyłączenia biegłego (art. $196 \S 1$ k.p.k.), a inaczej w przypadku, gdy wystąpiły powody osłabiające zaufanie do biegłego (art. $196 \S 3$ k.p.k.). W tym pierwszym przypadku sporządzona opinia - jak już wskazano - nie może stanowić dowodu, a zatem nie podlega zaliczeniu w poczet materiału dowodowego ${ }^{76}$. Natomiast $\mathrm{w}$ tym drugim przypadku ustawodawca nie przyjął takiego rozwiązania, co oznacza, że opinia wydana przez biegłego podlegającego wyłączeniu na podstawie art. $196 \S 3$ k.p.k. pozostaje dowodem w sprawie, podlegając ocenie na podstawie art. 7 k.p.k. i art. 201 k.p.k. ${ }^{77}$ Taki pogląd prezentowany jest $\mathrm{w}$ orzecznictwie ${ }^{78}$. W obu przypadkach należy powołać innego biegłego, ale tylko w tym pierwszym poprzednio wydana opinia nie może stanowić podstawy do wydania orzeczenia (art. 92 k.p.k. i art. 410 k.p.k.), co nie budzi wątpliwości w orzecznictwie ${ }^{79}$ i piśmiennictwie ${ }^{80}$. W postępowaniu

\footnotetext{
${ }^{75}$ A. Kegel, Z. Kegel, Przepisy o biegtych sądowych, tlumaczach $i$ specjalistach. Komentarz, Warszawa: Zakamycze 2004, s. 97.

${ }^{76}$ D. GRUSZECKA, Kodeks postępowania karnego, s. 476.

${ }^{77}$ Tamże.

${ }^{78}$ Wyrok SN z 16 grudnia 2008 r., WA 43/08, OSNwSK 2008, poz. 2610.

${ }^{79}$ Wyrok SA w Białymstoku z 20 marca 2014 r., II AKa 256/13, LEX nr 1496371; wyrok SA w Rzeszowie z 6 września 2012 r., II AKa 86/12, LEX nr 1223429.
} 
cywilnym - w świetle przytoczonego wyroku Sądu Najwyższego z 27 maja 1976 r. - zaistnienie każdej podstawy do wyłączenia biegłego prowadzi do dyskwalifikacji sporządzonej przez niego opinii. Tym samym w postępowaniu karnym, w przypadku wyłączenia biegłego i powołania innego na podstawie art. $196 \S 3$ k.p.k., organ procesowy dysponował będzie co najmniej dwiema opiniami, które podlegać będą ocenie ${ }^{81}$. W analogicznej sytuacji wystąpienia wątpliwości, odnośnie do bezstronności biegłego w toku postępowania cywilnego i podjęcia decyzji o jego wyłączeniu na podstawie art. 281 k.p.c., sąd cywilny nie będzie oceniał dotychczasowej opinii, a jedynie opinię złożoną przez nowego biegłego, nie odnosząc się w ogóle do tej pierwszej. Różnica między postępowaniem karnym a postępowaniem cywilnym jest więc w tej materii wyraźna i zasadnicza. Nadmienić należy, że w piśmiennictwie pojawił się pogląd, że w odniesieniu do przypadku, o którym mowa w art. $196 \S 3$ k.p.k. należy per analogiam stosować art. $196 \S 2$ k.p.k. Jako jego uzasadnienie podniesiono, że opinia stronniczego lub niekompetentnego biegłego nie może stanowić dowodu, a ponadto w razie sprzeczności między opinią biegłego wyłączonego i nowego biegłego konieczne byłoby przeprowadzenie konfrontacji biegłych, co byłoby niemożliwe ze względu na to, że wyłączony biegły nie może już występować w tej roli w procesie ${ }^{82}$. Przyjęcie tego poglądu oznaczałoby, że nie ma różnicy między postępowaniem cywilnym a postępowaniem karnym, albowiem w każdym przypadku wyłączenia biegłego złożona przez niego opinia nie może stanowić dowodu. Nie może być on jednak podzielony. Po pierwsze, treść art. 196 § 3 k.p.k. W zestawieniu z $\S 2$ tego artykułu jednoznacznie wskazuje, że tylko w przypadku, o którym mowa w $\S 2$ ustawodawca przewidział dyskwalifikację dowodu z opinii biegłego (,wydana przez niego opinia nie stanowi dowodu"). Takie rozwiązanie nie zostało przyjęte $\mathrm{w}$ odniesieniu do przypadku uregulowanego w art. $196 \S 3$ k.p.k. Po drugie, art. 201 k.p.k. nie przewiduje obligatoryjnej konfrontacji biegłych. Nie można zatem twierdzić, że w przypadku uznania, że opinia biegłego, o którym mowa w art. $196 \S 3$ k.p.k., stanowi dowód, niezbędne jest przeprowadzenie takiej czynności (konfrontacji). Po

\footnotetext{
${ }^{80}$ L.K. Paprzycki, [w:] J. Grajewski, L.K. PAPrzycki, S. Steinborn, Kodeks postepowania karnego. Komentarz, t. I, red. L.K. Paprzycki, Warszawa: Wolters Kluwer 2013, s. 677.

${ }^{81}$ D. Hajdukiewicz, Podstawy prawne opiniowania sadowo-psychiatrycznego $w$ postepowaniu karnym, w sprawach o wykroczenia oraz w sprawach nieletnich, Warszawa: Instytut Psychiatrii i Neurologii 2007, s. 84.

82 J. Misztal-Konecka, J. Konecki, Wytaczenie biegłego w postępowaniu karnym, „Prokuratura i Prawo" 2010, nr 7-8, s. 160-161.
} 
trzecie, z art. $196 \S 3$ k.p.k. nie wynika, że w odniesieniu do biegłego, który złożył opinię, należy wydać rozstrzygnięcie w przedmiocie jego wyłączenia. Ustawa procesowa nie przewiduje $\mathrm{w}$ tym przypadku formalnego wyłączenia biegłego (inaczej niż w przypadku, o którym mowa w art. $196 \S 2$ k.p.k.), a zatem nie można zasadnie twierdzić, że biegły określony w art. $196 \S 3$ k.p.k. nie może brać udziału w toczącym się postępowaniu karnym, zaś jego opinia nie może być dowodem w sprawie. W dacie złożenia opinii dana osoba była biegłym, zaś wystąpienie okoliczności, o których mowa w art. 196 § 3 k.p.k., nie odbiera złożonej opinii biegłego tego statusu. W konsekwencji nie można przenosić na grunt postępowania karnego rozwiązań wypracowanych w orzecznictwie Sądu Najwyższego na gruncie postępowania cywilnego. W postępowaniu karnym o tym, co nie stanowi dowodu, decyduje ustawa. Ze względów gwarancyjnych, w tym uwzględniając postulat pewności prawa, takie też rozwiązanie powinno być przyjęte w kodeksie postępowania cywilnego, tj. z art. 281 k.p.c. powinno wynikać, jakie są procesowe skutki wyłączenia biegłego w odniesieniu do złożonej przez niego opinii. Wprowadzenie takiego wyraźnego rozwiązania postuluję de lege ferenda.

\section{DOPUSZCZENIE DOWODU Z OPINII INNEGO BIEGŁEGO ZE WZGLĘDU NA „INNE WAŻNE POWODY”}

Konieczność dopuszczenia dowodu z opinii innego biegłego może wynikać z powodu zaistnienia przyczyny uniemożliwiającej sporządzenie opinii przez dotychczasowego biegłego. Kodeks postępowania karnego wyraźnie stanowi, że w sytuacji, gdy ujawnią się ,inne ważne powody”, powołuje się innego biegłego (art. $196 \S 3$ k.p.k.). Ustawa procesowa nie definiuje tego pojęcia. Jak wskazano w piśmiennictwie, „innymi ważnymi powodami” są obiektywne przeszkody, które uniemożliwiają sporządzenie opinii biegłego albo też uniemożliwiają sporządzenie jej w wyznaczonym przez sąd terminie, np. z powodu długotrwałej choroby czy wyjazdu na dłuższy czas za granicę, podkreślając przy tym, że $\mathrm{z}$ tych powodów należy przyjąć, że biegły, któremu znane są okoliczności uniemożliwiające mu sporządzenie opinii albo sporządzenie jej w wyznaczonym terminie, powinien o tym niezwłocznie zawiadomić organ, który go powołał. Podkreślono również, że nie są nimi te, które podważają zaufanie do wiedzy lub bezstronności biegłego, wskazując trafnie, że w art. $196 \S 3$ k.p.k. zwrot ,inne ważne powody” został umieszczony po powodach osłabiających zaufanie do wiedzy lub bez- 
stronności biegłego i został oddzielony funktorem zdaniotwórczym „albo" oznaczającym alternatywę rozłączną, a zatem ma on samodzielny byt ${ }^{83}$. W kodeksie postępowania cywilnego nie ma odpowiednika art. 196 § 3 k.p.k., stwarzającego podstawę do powołania innego biegłego ze względu na „ważne powody", ale uregulowano instytucję nieprzyjęcia obowiązków biegłego (art. 280 k.p.c.), co finalnie oznacza konieczność powołania innego biegłego. Wyraźnej regulacji w tej materii jednak nie wprowadzono, tj. w art. 280 k.p.c. nie wskazano, że w wyniku zwolnienia go od wydania opinii należy powołać innego biegłego, ale nie jest to mankament, albowiem w takim przypadku powołanie biegłego reguluje art. 278 k.p.c. W piśmiennictwie wskazano, że podejmując decyzję na podstawie art. 280 k.p.c., sąd powinien brać pod uwagę takie okoliczności, jak np. choroba biegłego, nadmierne obciążenie obowiązkami przy innych sprawach sądowych ${ }^{84}$, są to zatem okoliczności zbieżne z tymi, które mieszczą się w pojęciu „innych ważnych powodów” w rozumieniu art. $196 \S 3$ k.p.k. Zarówno na gruncie postępowania cywilnego, jak i postępowania karnego, okoliczności, o których mowa we wskazanych przepisach, odnoszą się do osoby biegłego, a nie jego opinii, nie są zatem związane z jej procesową oceną.

\section{PODSUMOWANIE}

W świetle powyższych uwag, zarówno w postępowaniu cywilnym, jak i karnym, dopuszczenie dowodu $\mathrm{z}$ opinii innego biegłego związane jest $\mathrm{z}$ :

1) oceną odnoszącą się do opinii złożonej w sprawie przez dotychczasowego biegłego czy też biegłych (pełność, jasność, brak sprzeczności wewnętrznej, brak sprzeczności z innymi opiniami w tej samej sprawie), tj. wady dotychczasowej opinii przesądzić mogą o konieczności powołania innego biegłego;

2) oceną odnoszącą się do osoby biegłego, w tym związaną z jego wiedzą i bezstronnością, tj. zaistnienie podstaw do wyłączenia biegłego jest równoznaczne z koniecznością powołania innego biegłego;

3) oceną odnoszącą się do możliwości sporządzenia opinii przez biegłego, który został powołany przez organ procesowy, tj. brak możliwości spo-

\footnotetext{
${ }^{83}$ R.A. STEFAŃSKI, Kodeks postępowania karnego, teza 5 do art. 196.

${ }^{84} \mathrm{~K}$. FlAGA-GIERUSZYŃSKA, Kodeks postępowania cywilnego, s. 587.
} 
rządzenia opinii przez biegłego, w tym w terminie zakreślonym przez organ procesowy, uzasadniać może powołanie innego biegłego.

W przypadku zaistnienia podstaw do wyłączenia biegłego dopuszczenie dowodu z opinii innego biegłego jest obowiązkiem organu procesowego, bez względu na to, czy stwierdzono wadliwość sporządzonej przez niego opinii, natomiast $\mathrm{w}$ przypadku ustalenia, że złożona opinia nie spełnia wymogów merytorycznych, organ procesowy władny jest zarówno ponownie wezwać dotychczasowych biegłych, jak również powołać innych. Brak możliwości sporządzenia opinii przez dotychczasowego biegłego determinuje konieczność powołania innego biegłego.

\section{BIBLIOGRAFIA \\ ŹRÓDŁA PRAWA}

Ustawa z dnia 17 listopada 1964 r. - Kodeks postępowania cywilnego, tekst jedn. Dz. U. 2019, poz. $1460 \mathrm{z}$ późn. zm.

Ustawa z dnia 19 kwietnia 1969 r. - Kodeks postępowania karnego, Dz. U. 1969, nr 13, poz. 96 z późn. zm.

Ustawa z dnia 6 czerwca 1997 r. - Kodeks postępowania karnego, tekst jedn. Dz. U. 2020, poz. 30.

Ustawa z z dnia 4 lipca 2019 r. o zmianie ustawy - Kodeks postępowania cywilnego oraz niektórych innych ustaw, Dz. U. 2019, poz. 1469.

\section{ORZECZNICTWO}

Postanowienie SN z 21 września 1975 r., Z 24/75, OSNKW 1975, nr 12, poz. 172.

Wyrok SN z 27 maja 1976 r., I PR 64/76, LEX nr 7830.

Wyrok SN z 20 kwietnia 1984 r., RNw 27/83, OSNPG 1984, nr 11, poz. 102.

Wyrok SN z 9 maja 1988 r., OSNKW 1988, nr 9-10, poz. 72.

Wyrok SN z 12 maja 1988 r., II KR 92/88, OSNKW 1989, nr 2, poz. 35.

Wyrok SN z 17 grudnia 1999 r., II UKN 273/99, LEX nr 46509.

Wyrok SN z 6 listopada 2002 r., IV KKN 308/99, LEX nr 56851.

Postanowienie SN z 26 czerwca 2008 r., V KK 206/08, OSNwSK 2008/1/1350.

Wyrok SN z 16 grudnia 2008 r., WA 43/08, OSNwSK 2008, poz. 2610.

Wyrok SN z 7 października 2009 r., III KK 122/09, LEX nr 532391.

Wyrok SA w Rzeszowie z 6 września 2012 r., II AKa 86/12, LEX nr 1223429.

Wyrok SA w Lublinie z 18 października 2012 r., II AKa 243/12, LEX nr 1237271.

Wyrok SA w Krakowie z 10 listopada 2012 r., II AKa 107/12, LEX nr 1293419.

Wyrok SA w Rzeszowie z 21 lutego 2013 r., II AKa 7/13, LEX nr 1280995.

Wyrok SN z 28 sierpnia 2013 r., V KK 80/13, LEX nr 1381068.

Wyrok SN z 3 marca 2014 r., WA 30/13, LEX nr 1460571. 
Wyrok SN z 11 marca 2014 r., WA 1/14, LEX nr 1444408.

Wyrok SA w Białymstoku z 20 marca 2014 r., II AKa 256/13, LEX nr 1496371;

Wyrok SA we Wrocławiu z 9 kwietnia 2014 r., II AKa 70/14, LEX nr 1459125.

Wyrok SN z 20 maja 2014 r., I UK 427/13, LEX nr 1511380.

Wyrok SA w Krakowie z 9 września 2015 r., I ACa 705/15, LEX nr 1820414.

Wyrok SN z 8 października 2015 r., I UK 447/14, LEX nr 1820395.

Wyrok SA w Gdańsku z 4 listopada 2015 r., III AUa 819/15, LEX nr 1950626.

Wyrok SN z 13 stycznia 2016 r., V CSK 262/15, LEX nr 2020486.

Wyrok SA w Gdańsku z 10 maja 2016 r., V ACa 776/15, LEX nr 2108564.

Postanowienie SN z 27 lipca 2016 r., V KK 25/16, LEX nr 2108096.

Wyrok SN z 4 sierpnia 2016 r., III UK 195/15, LEX nr 2155187.

Wyrok SA we Wrocławiu z 6 października 2017 r., II AKa 233/17, LEX nr 2412867.

Wyrok SA w Warszawie z 20 października 2017 r., II AKa 306/17, LEX nr 2402456.

Wyrok SA w Warszawie z 15 listopada 2017 r., VII ACa 1394/17, LEX nr 2487716.

Wyrok SA w Krakowie z 22 listopada 2017 r., I ACa 535/17, LEX nr 2472497.

Wyrok SA w Gdańsku z 26 stycznia 2018 r., V AGa 19/18, LEX nr 2522657.

Wyrok SA w Katowicach z 1 marca 2018 r., II AKa 568/17, LEX nr 2480854.

Postanowienie SN z 11 kwietnia 2018 r., III UK 111/17, LEX nr 2497990.

Wyrok SA w Białymstoku z 17 maja 2018 r., III APa 3/18, LEX nr 2546188.

Wyrok SA w Szczecinie z 22 maja 2019 r., I ACa 751/18, LEX nr 2704181.

Wyrok SA w Łodzi z 5 czerwca 2018 r., I AGa 167/18, LEX nr 2571390.

Wyrok SA w Krakowie z 21 czerwca 2018 r., I ACa 114/18, LEX nr 2545097.

Wyrok SA w Białymstoku z 25 lipca 2018 r., I ACa 129/18, LEX nr 2627840.

wyrok SA w Lublinie z 1 sierpnia 2018 r., III AUa 1074/17, LEX nr 2534791.

Wyrok SA w Warszawie z 3 sierpnia 2018 r., V ACa 546/17, LEX nr 2697349.

Wyrok SA w Poznaniu z 23 sierpnia 2018 r., I ACa 1495/17, LEX nr 2582655.

Wyrok SA w Gdańsku z 31 sierpnia 2018 r., V ACa 728/17, LEX nr 2629005.

Wyrok SA w Łodzi z 6 września 2018 r., I ACa 1759/17, LEX nr 2596528.

Wyrok SN z 19 września 2018 r., I CSK 578/17, LEX nr 2566916.

Wyrok SA w Warszawie z 28 września 2018 r., I ACA 467/17, LEX nr 2581364.

Wyrok SA w Krakowie z 2 października 2018 r., II AKa 254/18, LEX nr 2645335.

Wyrok SA w Lublinie z 10 października 2018 r., III AUa 195/18, LEX nr 2574809.

Wyrok SA w Lublinie z 16 października 2018 r., II AKa 229/18, LEX nr 2576169.

Wyrok SA we Wrocławiu z 18 października 2018 r., II AKa 128/18, LEX nr 2605253.

Wyrok SN z 24 października 2018 r., II CSK 623/17, LEX nr 2567918.

Wyrok SA w Szczecinie z 13 listopada 2018 r., III AUa 343/18, LEX nr 2729123.

Wyrok SA w Gdańsku z 14 listopada 2018 r., V ACa 16/18, LEX nr 2638969.

Wyrok SA w Szczecinie z 27 listopada 2018 r., I ACa 692/16, LEX nr 2624150. 
Wyrok SA w Białymstoku z 28 listopada 2018 r., I ACa 522/18, LEX nr 2691738. Wyrok SA w Łodzi z 30 listopada 2018 r., I ACa 1736/17, LEX nr 2625568. Wyrok SA w Białymstoku z 3 grudnia 2018 r., I ACa 507/18, LEX nr 2627851. Wyrok SA we Wrocławiu z 5 grudnia 2018 r., II AKa 181/18, LEX nr 2609436. Wyrok SA w Szczecinie z 9 stycznia 2019 r., I ACa 689/18, LEX nr 2668037. Wyrok SA w Gdańsku z 14 stycznia 2019 r., V AGa 138/18, LEX nr 2673410. Wyrok SA w Warszawie z 24 stycznia 2019 r., VII AGa 606/18, LEX nr 2725368. Wyrok SA w Białymstoku z 31 stycznia 2019 r., I ACa 673/18, LEX nr 263043. Wyrok SN z 15 lutego 2019 r., II CSK 723/17, LEX nr 2621120.

Wyrok SA w Szczecinie z 27 lutego 2019 r., I ACa 449/18, LEX nr 2668147. Wyrok SA w Białymstoku z 28 lutego 2019 r., I ACa 792/18, LEX nr 2741655. Wyrok SA w Białymstoku z 28 lutego 2019 r., I ACa 49/18, LEX nr 2728131. Wyrok SA w Gdańsku z 28 lutego 2019 r., V AGa 199/18, LEX nr 2696112. Wyrok SA w Warszawie z 5 marca 2019 r., III AUa 956/17, LEX nr 2704894. Wyrok SA w Szczecinie z 12 marca 2019 r., I ACa 785/16, LEX nr 2668080. Wyrok SA w Lublinie z 27 marca 2019 r., III AUa 759/18, LEX nr 2669287. Wyrok SA w Szczecinie z 28 marca 2019 r., I ACa 612/18, LEX nr 2668049. Wyrok SN z 12 kwietnia 2019 r., I CSK 166/18, LEX nr 2647531.

Wyrok SA w Krakowie z 16 kwietnia 2019 r., I AGa 479/18, LEX nr 2777802. Wyrok SA w Warszawie z 26 kwietnia 2019 r., I ACa 88/17, LEX nr 2753901. Wyrok SA w Białymstoku z 9 maja 2019 r., II AKa 58/19, LEX nr 2735140. Wyrok SA w Lublinie z 9 maja 2019 r., III AUa 307/18, LEX nr 2679335. Wyrok SA w Warszawie z 13 maja 2019 r., I ACa 1478/15, LEX nr 2680704. Wyrok SA w Gdańsku z 24 maja 2019 r., V AGa 224/18, LEX nr 2702646. Wyrok SA w Białymstoku z 29 maja 2019 r., I ACa 797/18, LEX nr 2713669. Wyrok SA w Krakowie z 5 czerwca 2019 r., I ACa 87/19, LEX nr 2784445. Wyrok SA w Krakowie z 13 czerwca 2019 r., I ACa 366/18, LEX nr 2780936. Wyrok SA w Krakowie z 4 lipca 2019 r., I ACa 814/18, LEX nr 2799256. Wyrok SA w Lublinie z 31 lipca 2019 r., III AUa 317/19, LEX nr 2706237. Wyrok SA w Warszawie z 7 sierpnia 2019 r., V ACa 587/18, LEX nr 2726862. Wyrok SA w Lublinie z 11 września 2019 r., III AUa 40/19, LEX nr 2724215. Wyrok SA w Warszawie z 19 września 2019 r., I ACa 483/18, LEX nr 2728639. Wyrok SA w Szczecinie z 20 września 2019 r., I ACa 395/18, LEX nr 2728623. Wyrok SA w Szczecinie z 24 września 2019 r., I ACa 403/19, LEX nr 2770874. Wyrok SA w Szczecinie z 3 października 2019 r., I ACa 459/19, LEX nr 2771942. Wyrok SA w Warszawie z 9 października 2019 r., II AKa 148/19, LEX nr 2750301. Wyrok SA w Białymstoku z 10 października 2019 r., III AUa 272/19, LEX nr 2781357. Wyrok SA w Warszawie z 16 października 2019 r., I ACa 520/18, LEX nr 2753902. 
Wyrok SA w Gdańsku z 13 listopada 2019 r., V ACa 518/19, LEX nr 2797440.

Wyrok SA w Lublinie z 27 listopada 2019 r., III AUa 617/19, LEX nr 2758369.

Wyrok SA w Lublinie z 6 grudnia 2019 r., I ACa 774/18, LEX nr 2799116.

\section{LITERATURA}

CichORSKA Monika: [w:] Kodeks postępowania cywilnego. Koszty sądowe w sprawach cywilnych. Dochodzenie roszczeń w postępowaniu grupowym. Przepisy przejściowe, t. I, red. T. Zembrzuski, Warszawa: Wolters Kluwer 2020, komentarz do art. 286.

DZIERŻANOwSKA Joanna, STUDZIŃSKA Joanna: Kryteria oceny dowodu z opinii biegłego w orzecznictwie sądów powszechnych i Sądu Najwyższego, ,Roczniki Nauk Prawnych” 25(2015), nr 2, s. 21-47.

DZIERŻANOwSKA Joanna, STUDZIŃSKA Joanna: Komentarz do niektórych przepisów kodeksu postępowania cywilnego, [w:] Joanna DZIERŻANowsKA, Joanna STUDZIŃSKA, Biegli w sądowym postępowaniu cywilnym i karnym. Praktyczne omówienie regulacji z orzecznictwem, Warszawa: Wolters Kluwer 2019, komentarz do art. 286.

EReCiŃSKi Tadeusz: [w:] EREciŃSKi Tadeusz, Gudowski Jacek, JęDrZEJEwSKA Maria: Komentarz do kodeksu postępowania cywilnego. Część pierwsza. Postępowanie rozpoznawcze, t. 1, red. T. Ereciński, Warszawa: LexisNexis 2003, komentarz do art. 286.

FlAGA-GIERUSZYŃSKA Kinga: [w:] Kodeks postępowania cywilnego. Komentarz, red. Kinga Flaga-Gieruszyńska, Maciej Zieliński, Warszawa: C.H. Beck 2019, komentarz do art. 278, 280 i 286.

GRUSZECKA Dagmara: [w:] Kodeks postępowania karnego. Komentarz, red. J. Skorupka, Warszawa: Wolters Kluwer 2015, komentarz do art. 201.

GRZEGORCZYK Tomasz: Kodeks postępowania karnego oraz ustawa o świadku koronnym. Komentarz, Warszawa: Lex 2008, komentarz do art. 201.

HABZDA-SiweK Ewa: Diagnoza stanu psychicznego sprawcy a rozstrzygnięcia w procesie karnym, Kraków: Zakamycze 2002

HAJDUKIEwicz Danuta: Podstawy prawne opiniowania sądowo-psychiatrycznego w postępowaniu karnym, w sprawach o wykroczenia oraz w sprawach nieletnich, Warszawa: Instytut Psychiatrii i Neurologii 2007

HofMAŃSKI Piotr, SADZIK Elżbieta, ZGRYZEK Kazimierz: Kodeks postępowania karnego. Tom I. Komentarz do artykułów 1-296, red. P. Hofmański, Warszawa: C.H. Beck 2011, komentarz do art. 201.

KALINOwSKI Stefan: [w:] Kodeks postępowania karnego. Komentarz, red. M. Mazur, Warszawa: Wydawnictwo Prawnicze 1976, komentarz do art. 182.

Kegel Anna, Kegel Zdzisław: Przepisy o biegłych sądowych, tłumaczach i specjalistach. Komentarz, Warszawa: Zakamycze 2004, komentarz do art. 196.

KŁAK Czesław: Powołanie innego biegłego w polskim procesie karnym. Problematyka oceny dowodu z opinii biegłego w kontekście art. 193, 196, 201 i 202 § 3 k.p.k., „Problemy współczesnej kryminalistyki" 2006, t. 10, s. 107-124.

KUROwSKI Michał: [w:] Kodeks postępowania karnego. Komentarz, t. I, red. D. Świecki, Warszawa: Wolters Kluwer 2013, komentarz do art. 196.

MiszTAL-KoneCKA Joanna, KonECKI Janusz: Wyłączenie biegłego w postępowaniu karnym, „Prokuratura i Prawo” 2010, nr 7-8, s. 149-164. 
PAPKE-OlSZAUSKAS Katarzyna: Wyłączenie uczestników procesu karnego, Gdańsk: Wydawnictwo Uniwersytetu Gdańskiego 2007.

PAPRZYCKI Lech Krzysztof: [w:] GRAJEwSKI Jan, PAPRZYCKI Lech Krzysztof, STEINBORN Sławomir, Kodeks postępowania karnego. Komentarz, t. I, red. L.K. Paprzycki, Warszawa: Wolters Kluwer 2013, komentarz do art. 196.

STEFAŃSKI Ryszard Andrzej: [w:] Kodeks postępowania karnego. Komentarz, t. II, red. R.A. Stefański i S. Zabłocki, Warszawa: Wolters Kluwer 2016, komentarz do art. 196 i 201.

TOMASZEwSKI Tadeusz: Dowód z opinii biegłego w procesie karnym, Kraków: Wydawnictwo Instytutu Ekspertyz Sądowych 2000.

WIDŁA Tadeusz: Ocena dowodu z opinii biegłego, Katowice: Uniwersytet Śląski 1992.

\section{DOPUSZCZENIE DOWODU Z OPINII INNEGO BIEGŁEGO W POLSKIM POSTĘPOWANIU CYWILNYM I KARNYM. PODOBIEŃSTWA I RÓŻNICE}

\section{Streszczenie}

Artykuł dotyczy problematyki dopuszczenia dowodu z opinii innego biegłego w świetle kodeksu postępowania cywilnego i kodeksu postępowania karnego. W postępowaniu cywilnym nie określono przesłanek zasięgnięcia opinii innego biegłego, podczas gdy w postępowaniu karnym wyraźnie określono, kiedy dopuszczalne jest podjęcie takiej decyzji. Mimo tego, w orzecznictwie Sądu Najwyższego zasadnie przyjęto, że sąd w postępowaniu cywilnym nie ma dowolności w powoływaniu kolejnych biegłych, a u podstaw takiej decyzji leżeć powinny racjonalne argumenty, takie jak np.: niejasność, niezupełność czy sprzeczności występujące w opiniach. Zarówno na gruncie kodeksu postępowania cywilnego, jak i na gruncie kodeksu postępowania karnego, nie ulega wątpliwości, że dopuszczenie dowodu z opinii innego biegłego nie jest dopuszczalne tylko i wyłącznie dlatego, że opinia nie przekonuje strony czy też jest dla niej niekorzystna. Dopuszczenie dowodu $\mathrm{z}$ opinii kolejnego biegłego jest w takim przypadku niedopuszczalne, nie znajduje bowiem żadnej podstawy normatywnej. Zdaniem Autora, przepisy proceduralne w jednakowy sposób powinny regulować kwestię dopuszczenia dowodu $\mathrm{z}$ opinii innego biegłego, nie ma bowiem żadnego uzasadnienia, aby inne rozwiązania obowiązywały w postępowaniu cywilnym, a inne w postępowaniu karnym. Z przepisów powinno w sposób jednoznaczny wynikać, kiedy możliwe jest dopuszczenie dowodu z opinii innego biegłego, tj. jakie są przesłanki podjęcia takiej decyzji, jak również $\mathrm{w}$ jakim następuje to trybie. $\mathrm{W}$ tej materii rozwiązanie przyjęte $\mathrm{w}$ kodeksie postępowania karnego jest bardziej precyzyjne, zaś przepisy kodeksu postępowania cywilnego mają charakter zbyt ogólny.

Słowa kluczowe: opinia biegłego; ocena dowodu z opinii biegłego w postępowaniu karnym i postępowaniu cywilnym 


\title{
ADMISSION OF EVIDENCE FROM THE OPINION OF ANOTHER EXPERT IN POLISH CIVIL AND CRIMINAL PROCEEDINGS. SIMILARITIES AND DIFFERENCES
}

\begin{abstract}
Summary
The article concerns the issue of admitting evidence from the opinion of another expert in the light of the Code of Civil Procedure and the Code of Criminal Procedure. In civil proceedings, there are no prerequisites for seeking the opinion of another expert, while in criminal proceedings it is clearly specified when such a decision is allowed. Despite this, the jurisprudence of the Supreme Court reasonably assumed that the court in civil proceedings is not free to appoint further experts, and that such decision should be based on rational arguments, such as ambiguity, incompleteness or contradictions appearing in opinions. Both under the Code of Civil Procedure and under the Code of Criminal Procedure, there is no doubt that admission of evidence from the opinion of another expert is not permissible only because the opinion does not convince the party or is detrimental to it. Admission of evidence from the opinion of another expert is in this case inadmissible, as it has no normative basis. According to the author, procedural provisions should regulate the issue of admitting evidence from the opinion of another expert in the same way, as there is no justification for other solutions to apply in civil proceedings and others in criminal proceedings. The provisions should clearly show when it is possible to admit evidence from the opinion of another expert, i.e. what are the conditions for making such a decision, as well as the procedure followed. In this matter, the solution adopted in the Code of Criminal Procedure is more precise, and the provisions of the Code of Civil Procedure are too general.
\end{abstract}

Key words: expert opinion; assessment of evidence from an expert opinion in criminal and civil proceedings 